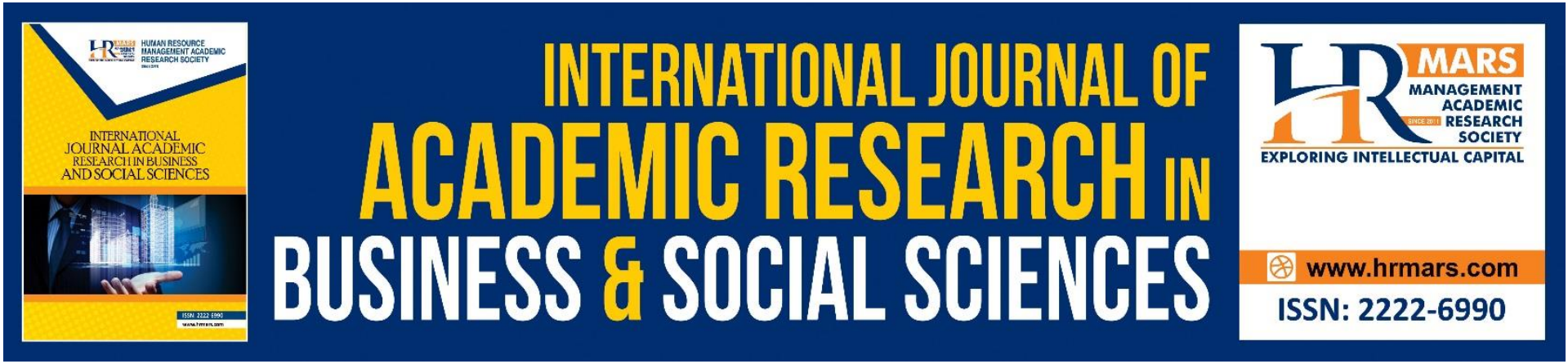

\title{
Designing and Incorporating Personalized Learning Analytics: Examining Self-Regulated Meaningful Learning
}

Muhammad Izzat Izzuddin bin Zainuddin and Hairulliza Mohamad Judi

To Link this Article: http://dx.doi.org/10.6007/IJARBSS/v11-i12/11327

DOI:10.6007/IJARBSS/v11-i12/11327

Received: 18 October 2021, Revised: 20 November 2021, Accepted: 30 November 2021

Published Online: 23 December 2021

In-Text Citation: (Zainuddin \& Judi, 2021)

To Cite this Article: Zainuddin, M. I. I. bin, \& Judi, H. M. (2021). Designing and Incorporating Personalized Learning Analytics: Examining Self-Regulated Meaningful Learning. International Journal of Academic Research in Business and Social Sciences, 11(12), 2276-2287.

Copyright: @ 2021 The Author(s)

Published by Human Resource Management Academic Research Society (www.hrmars.com)

This article is published under the Creative Commons Attribution (CC BY 4.0) license. Anyone may reproduce, distribute, translate and create derivative works of this article (for both commercial and non0-commercial purposes), subject to full attribution to the original publication and authors. The full terms of this license may be seen at: http://creativecommons.org/licences/by/4.0/legalcode

Vol. 11, No. 12, 2021, Pg. 2276- 2287

http://hrmars.com/index.php/pages/detail/IJARBSS

JOURNAL HOMEPAGE

Full Terms \& Conditions of access and use can be found at http://hrmars.com/index.php/pages/detail/publication-ethics 


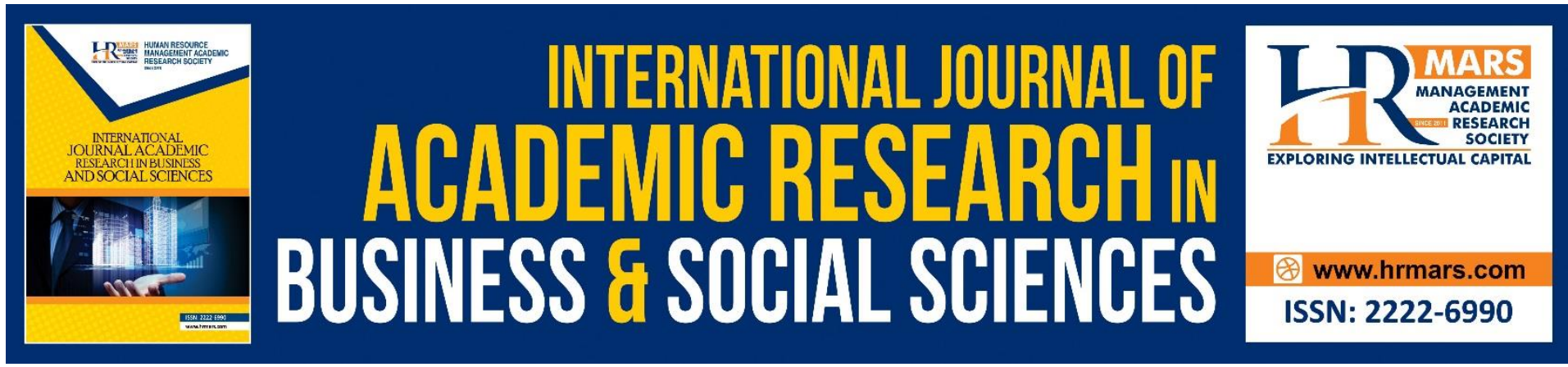

\title{
Designing and Incorporating Personalized Learning Analytics: Examining Self-Regulated Meaningful Learning
}

\author{
Muhammad Izzat Izzuddin bin Zainuddin and Hairulliza \\ Mohamad Judi \\ Faculty of Information Science and Technology, Universiti Kebangsaan Malaysia, 43600 UKM \\ Bangi, Selangor Darul Ehsan, Malaysia \\ Email: hmj.ftsm@gmail.com
}

\begin{abstract}
Education in the normal era post-pandemic implements flexible learning to allow students to choose learning places and steps by integrating students and technology to enable new possibilities aimed at effective learning. However, students encounter tremendous challenges of losing learning focus for not giving the necessary commitment or enough attention to deal with learning tasks. This learning problem may create a severe issue if not detected from the beginning and addressed systematically. Learning analytics can monitor learning progress and identify the learning problems of individual students. Several previous studies focus on the analytical framework of learning, but attention to meaningful learning and the development of problem-solving skills is still insufficient. This paper aims to propose a self-regulated meaningful analytic learning framework that promotes problem-solving skills. The framework aims to guide educators and administrators in the new normal in implementing personalised learning analytics in self-regulated meaningful learning. The employment of meaningful learning strategies supported by learning analytics help students prepare the skills needed to match their individual needs.
\end{abstract}

Keywords: Learning Analytics, Personalized, Meaningful Learning, Self-regulated Learning

\section{Introduction}

Education in normal era post-pandemic implements flexible learning regardless of the learning time, place and steps. Flexible learning occurs by integrating people and technology to enable new possibilities aimed at effective learning. Among the learning goals in education in the New Normal is to provide students with the problem-solving skills required by the industry. Learning encourages students to give meaning to the concepts they learn and apply them in real life.

In line with Education in the New Normal, online learning leverages technology to support learning activities. Although technologies such as social media carry the potential to enable student-oriented pedagogy to be carried out (Wieser, 2019), students face various related problems that lack the attention of educators (Liu \& Huang, 2017). 
Learning problems in education in the New Normal involve the potential of students to lose control in their learning tasks that require students to play an essential role in self-learning (Janati et al., 2019). These problems are related to the different backgrounds, abilities and tendencies of each student, which can lead to learning resource constraints and a lack of learning motivation (Corrin et al., 2016; Haron, 2018)

If not detected from the beginning and addressed systematically, the problem of losing the focus of learning will endanger more severe issues. The issue relates to higher education institutions' role in providing education in the New Normal to be not implemented effectively (Fox, 2020). Problems of student involvement in learning also affect in-depth understanding and also affect the development of problem-solving skills (Aker et al., 2019)

The mentioned problem also affects the learning goals in education in the New Normal, which involve technical capabilities and problem-solving skills (Selamat, 2017). Furthermore, problem-solving skills appear to be among the primary skills of graduates in the job market in 2015 and 2020 (Haron, 2018). Problem-solving skills remain relevant to human resource development. However, much of the job market in the IR 4.0 industry, especially the manufacturing sector, is taken over by robots, artificial intelligence and automation. The problem-solving requirements remain relevant in the market, such as critical thinking, empathy-based management and decision-making (Thannimalai \& Raman, 2018).

Technology in Education in the New Normal can generate various data, including student information and learning performance (Selamat, 2017). The system requires learning analytics that supports policy development and decisions related to educational activities to use this data. Learning analytics can help quality decisions, contributing to a better understanding of situations and learning problems for individual students(Liu \& Huang, 2017; Ramli et al., 2019). Learning analytics require integration with meaningful learning strategies and designs capable of supporting self-learning to stimulate students to apply knowledge for real-life use and problem-solving (Chuan et al., 2019; Hairulliza et al., 2019). In-depth studies on the contribution of meaningful learning and learning analytics to problem-solving skills in education in the New Normal have not yet been thoroughly researched. Hence, more research is needed to understand how educators and students play their role as learning facilitators and learning centres in this context (Amran et al., 2021; Corrin et al., 2016).

Several previous studies have focused on the analytical framework of learning, but attention to meaningful learning and skill development in that context has not been sufficient. Existing studies lead to emotional-social understanding in learning analytical environments (Noroozi et al., 2019), a learning analytics framework to support learning in general (Dey et al., 2018), and a learning analytics framework to support adaptive learning to monitor student activities (Etemadpour et al., 2020).

Thus, this study proposes a framework that guides teachers and administrators in education in the New Normal, implementing blended learning means supported by learning analytics to help students effectively prepare them with the skills needed to match their needs individually. This paper aims to propose a self-regulated meaningful analytic learning framework that promotes problem-solving skills.

\section{Personalised Learning Analytics in Self-Regulated Learning}

Learning analytics is the measurement, collection, analysis and reporting of data about students and their context for understanding and optimising learning and the environment in which it occurs (Saqr, 2018). Learning Analytics is a fast-growing research discipline that uses insights generated from data analysis to support students and optimise learning processes 
and learning environments. Learning Analytics is driven by the availability of extensive data records on students, the expansion of the big data method revolution, cheaper and faster hardware, and the successful implementation of analytics in other domains (Liu \& Huang, 2017). The growth of online learning since the 1990s, particularly in higher education, has contributed to learning analytics as student data is available and ready for analysis.

Personalised learning analytics suggests using intelligent data, student-generated data, and analytical models to find information and social relationships to predict and advise one's learning (Nguyen et al., 2021). Personalised learning analytics serve as essential functions in the learning system. The tool can provide tailored support to the students, covering learning guidance, feedback, and learning sources, based on their needs (Abed \& Dalbir, 2020; Serban \& loan, 2020).

Personalised learning analytics support students in the learning process in various ways. First, as a generic design framework to monitor the learning process (Vaithilingam et al., 2019). A learning curve can function holistically as a framework that can act as a valuable guide for completing analytical services to monitor learning performance. This analysis is a practice of student education and guidance in quality assurance, curriculum development, and improving teachers' effectiveness and efficiency. The structure creates an avenue for the students to design their curriculum within the framework developed with inputs from the industry.

Second, as a data-based decision maker to help students grow in the learning progress (Pelikan et al., 2021), the broader term "analysis" has been defined as the science of examining data to conclude and, when used in decision making, to present a path or direction of action. From this perspective, learning analytics appear as a particular case of analytics, where decision making aims to enhance learning and education. Throughout the 2010s, these analytical definitions have gone further to include elements of operational research such as decision trees and strategy maps to define predictive models and determine probabilities for specific actions.

Third, as a data science application. Combined learning analytical models focus on student models in learning activities to adapt the student experience individually (Janati et al., 2019). However, many unresolved problems make it difficult for teachers to obtain appropriate information about student behaviour. The evolution of learning analytics offers new possibilities for problem-solving through intelligence work figures to monitor and manage student performance more effectively. The proposed system architecture prioritises databases that respond to these problems. It determines the specifics of learning dimensions and magnitudes, which helps educators and instructors to evaluate and analyse student activities. Through this interaction analysis, adaptive e-learning analytics can provide a predictive perspective on future challenges. These predictions assess the adaptation of content presentation and improve the performance of the learning process.

This analytical learning curve is at the crossroads of three disciplines: data science, learning theory and design. In data science, computational methods and techniques aim for data collection, pre-processing, analysis, and presentation. Learning theories emerge from learning, education, psychology, sociology, and philosophy literature. Model design dimensions include learning design, interaction design, and study design. A knowledge model needs to be linked to existing educational research so that learning analytics can fulfil its promise to understand and optimise learning (Noroozi et al., 2019).

Fourth, academic monitoring assists students in their learning (Fan et al., 2021). By monitoring students' learning and perseverance, the analytics may detect learning behaviours and 
unwanted emotional states and identify at-risk students in advance. Further, the analytics recognise factors that cause student dropouts or retention using predictive models. Instructors can take prompt follow-up action and provide appropriate assistance to students needing additional support, such as giving guidance, suggesting learning resources, and formulating individual learning plans. Students' level of achievement, as well as their retention, can be improved.

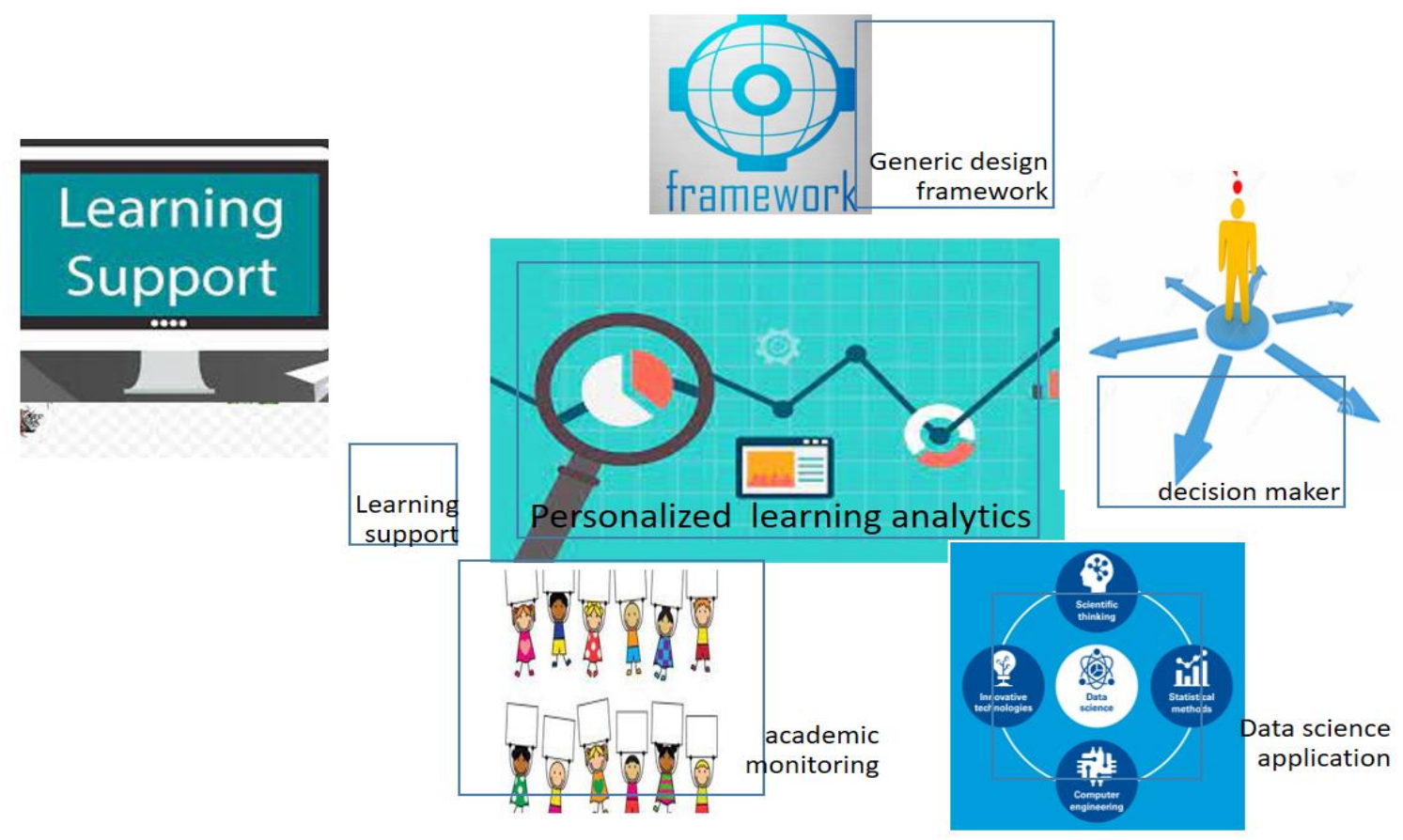

Fig. 1. Purpose of personalised learning analytics

\section{Self-Regulated Meaningful Learning}

Meaningful learning emphasises giving meaning to the learned concepts and relating them in cognitive structure (Vallori, 2014). The benefits of this approach encourage authentic learning and the application of learned concepts to the real world (Guimarães et al., 2018; Priniski et al., 2018). Learning is self-regulated to develop knowledge and problem-solving (Bakar et al., 2017; Chuan et al., 2019; Ismail \& Groccia, 2018; Yahaya et al., 2020). Meaningful learning content is enriched with techniques to apply active, authentic, constructive, cooperative and goal-based elements (Fan et al., 2015; Roslinda et al., 2018). Meaningful learning leverages the use of technology to implement self-regulated learning (Fox, 2020; Garfield \& Ben-zvi, 2009) as a practical way of obtaining information as almost everything is at your fingertips (Gikas \& Grant, 2013).

Thus, learning strategies are focused on deepening the concepts learned and applying them in the context of life (Rosly \& Khalid, 2017). Outlined as the primary skills of graduates in the job market in 2015 and 2020, problem-solving is considered a requirement $t$ in the context of higher learning (Haron, 2018). Problem-solving skills involve identifying essential components of the problem, identifying the cause of the problem, publishing important information, and submitting suggestions (Maisurah \& Bahador, 2012). The aspirations of students in education in the New Normal also outlined present technical skills covering problem-solving as learning goals (Hussin, 2018; Selamat, 2017). Learning objectives require analytical support of learning. Learning analytics involves the process of measuring, generating, analysing and 
reporting student-related data to understand and improve learning effectiveness (Corrin et al., 2016).

Learning analytics can be a helpful approach due to the various forms of data available for that purpose (Munguia et al., 2020). Learning curriculum, learning analytics and learning technology should be aligned to ensure the sustainability of education, especially with the rapid changes brought about by technology and the tendencies of the younger generation (Vaithilingam et al., 2019).

A meaningful learning framework and learning analytics are needed to support the challenges faced by higher education institutions to prepare graduates with the skills required by the industry (Selamat, 2017). This framework serves as a guide to implement effective learning in education in the New Normal, which emphasises learning development. For example, learning analytical frameworks can support learning appropriate to individual students (Nguyen et al., 2020), ensure a conducive environment for emotional construction and social interaction (Liu \& Huang, 2017), and encourage adaptation of learning strategies appropriate to student choice activities (Dey et al., 2018).

Education in the New Normal is the education sector's response to developments in the IR 4.0 era that integrate human beings and technologies to enable new possibilities aimed at effective learning (Hussin, 2018). Flexible learning occurs when learning applications utilise augmented reality, visualisation, virtual reality support learning in this era (Hairulliza, Iksan, et al., 2018; Majid \& Majid, 2018). Although there are many changes to the virtual learning environment, Education in the New Normal does not underestimate the learning experience but strengthens it by making full use of technology (Thannimalai \& Raman, 2018; Xing \& Marwala, 2017).

Six patterns in education in the New Normal show the transition of learning centres to students and no longer shouldered by instructors (Fisk, 2017). Instructors support the new structures without feeling this environment threatens their teaching careers (Hussin, 2018). The pattern is summarised as follows.

1. Learning on the go, matched to individual students.

2. Students have the option of determining how they learn.

3. Students complete project-based learning.

4. Students develop learning experiences through visits and collaboration.

5. Students are exposed to data interpretation and make reasoning skills.

6. Students are assessed differently based on their skills.

\section{Learning Analytics Design in Self-Regulated Meaningful Learning}

The self-regulated learning cycle contains three primary components: plan, monitor, and evaluate (Song \& Hill, 2007). These three components allow students to actively interact, control their learning environment, and keep track of their progress (Aguila-Gomez, 2016). Planning in online learning will enable students to organise knowledge by setting achievable goals to manage their own time and task (Pelikan et al., 2021). Students need to monitor their progress in online learning, which requires them to decide whether they understand the concept correctly and head in the next direction within their learning tasks (Karatas \& Arpaci, 2021). Students may choose various metacognitive strategies to check progress towards goal achievement, adjust learning strategies when necessary, mobilise learning resources, regulate their motivation and decide the right time to seek help (Viberg et al., 2020). Despite the flexibility in managing their learning, students face challenges to keep motivated and do 
the essential role due to uncertainty in evaluating their understanding and peers' knowledge (Song \& Hill, 2007).

The Achievement goal theory conceptualises two types of student motivation orientation in self-directed learning (Gielen et al., 2010). First, mastery, which focuses on developing personal competence, aims to obtain an individual learning goal. Second, the purpose of performance focuses on demonstrating competence over others works externally among peers. Learning interventions consist of early warning systems that track students' progress to identify whether they are at risk (Viberg et al., 2020). The student advisor or instructor in the course can then look at the information provided by the early warning system and act accordingly. The results show that the mastery approach decreases over time, indicating that the analytical intervention of learning correlates negatively with the mastery approach. To increase their success, students need information that helps them track:

- what is their active participation compared to other students in this course;

- how successful they are in comparison to other students in this course;

- whether they adhere to the learning schedule.

Meaningful learning suggests students create a strategy to design and plan their learning achievement. With an apparent attempt to focus on students' ability to control their learning journey, the learning environment trains students to deal with their role in the learning process. The system allows students to track their activities and success rates during learning and participate in self-learning evaluation. The goal should be clear and attainable within a set period. The course educators have processed each purpose to ensure that these online learning objectives are achieved.

Learning analytics support self-regulated learning in many ways. Learning analytics is driven by collecting and analysing footprints left by students. These data help instructors understand and optimise the learning process and the environment in which it occurs. To date, learning analytics mainly provide feedback to users on the web-based learning interface. The advance can support increased awareness and reflection and peer individual performance, suggest activities or additional learning content, and impact learning behaviour. For example, monitoring the situation in learning activities can motivate students to achieve learning goals. This cognitive process reflects as self-monitoring and understanding how to learn.

In the intended self-regulated learning environment, learning analytics facilitate students' adoption of self-directed learning. The proposed platform presents a set of visualised metrics that students and educators could filter to monitor their progress compared to their cohort. Figure 2 shows the facilities to guide the analysis and suggest how and when the data may appear beneficial. 


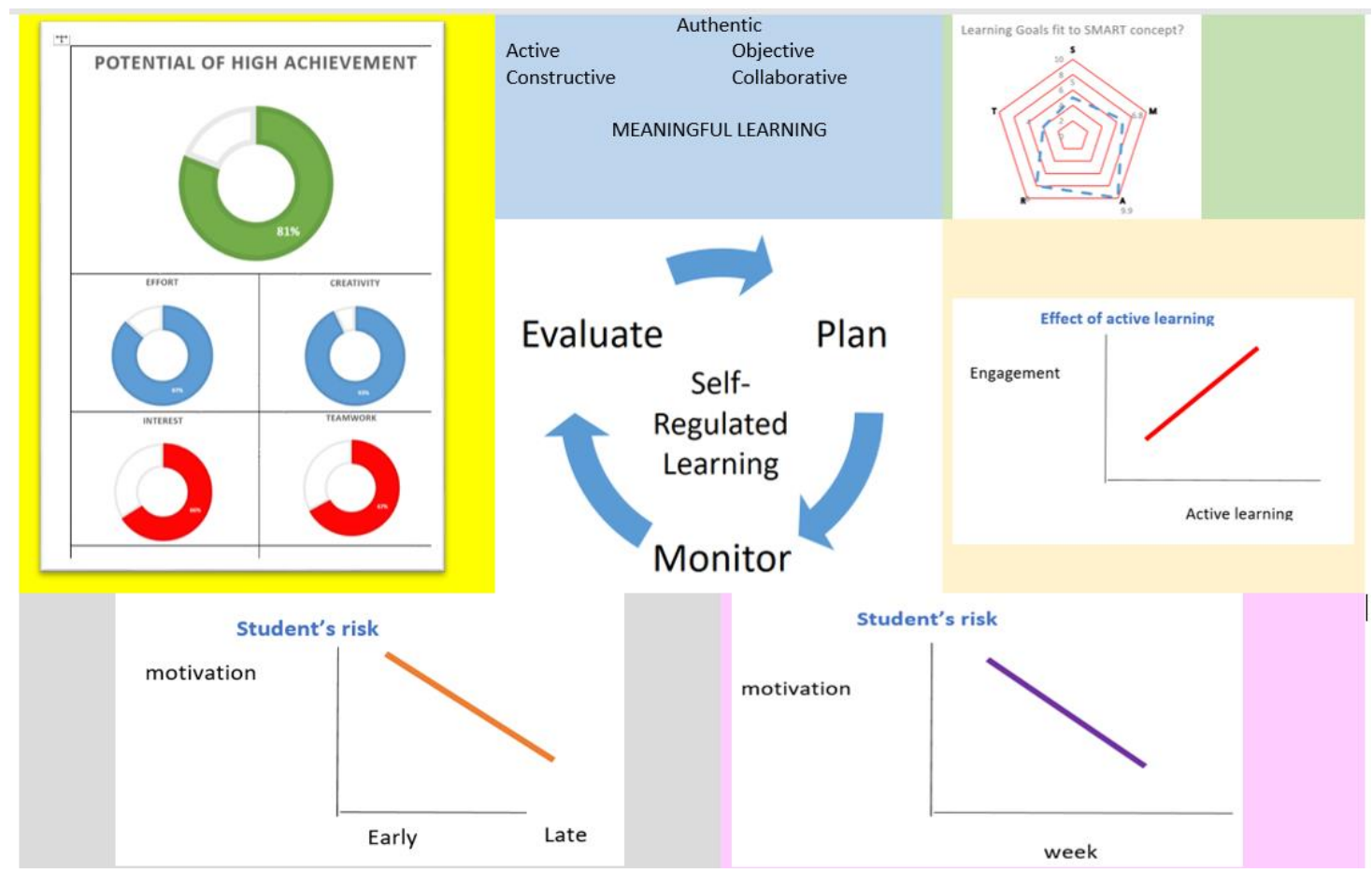

Fig. 2. Design of personalised learning analytics in self-regulated meaningful learning

\section{Conclusions}

The research proposes a self-regulated meaningful learning framework to emphasise the mapping of active, constructive, authentic, collaborative, and objective learning patterns. The customised measures in learning analytics for active or productive learning envision the commitment to initiate learning, curiosity, autonomy in a self-controlled manner. Learning analytics facilitate the adoption of self-directed learning and are used by students in a set of visualised metrics to be integrated with a learning management system to filter students learning difficulties. The facility helps educators monitor learning performance and progress compared to their cohort. Suggestions to improve monitoring include continuous assessment in the beginning, middle and towards the end of the learning stage.

Unlike the physical learning environment, serious problems arise in education in the New Normal. Due to current and drastic changes in the learning environment, learning difficulties and situations require attention start from the beginning to be addressed systematically. Personalised learning analytics provides the ability to analyse, report, and process information produced by individual students.

\section{Acknowledgement}

This work was supported by the Universiti Kebangsaan Malaysia under Grant GGP-2019-022. 


\section{References}

Abed, M. M., \& Dalbir, S. (2020). Clickstream data schema for learning analytics to understand learner behaviour. International Journal of Advanced Trends in Computer Science and Engineering, 9(5), 7223-7229. https://doi.org/10.30534/ijatcse/2020/49952020

Aguila-Gomez, M. (2016). Motivated Strategies for Learning and Students' Achievement in Biological Science using Self-Regulated Learning. International Journal of Academic Research in Progressive Education and Development, 5(4), 2226-6348. https://doi.org/10.6007/IJARPED/v5-i4/2453

Aker, M., Javier, L., \& Herrera, P. (2019). Smart Literacy Learning in the Twenty-First Century : Facilitating PBSL Pedagogic Collaborative Clouds. In Emerging Technologies and Pedagogies in the Curriculum, Bridging Human and Machine: Future Education with Intelligence (pp. 429-445). Springer Singapore. https://doi.org/10.1007/978-981-150618-5

Amran, N., Bahry, F. D. S., \& Yu, H. (2021). Distance Learners' Attributes in Optimizing Learning Achievement Using Learning Analytics. International Journal of Academic Research in Business and Social Sciences, 11(1), 441-453. https://doi.org/10.6007/ijarbss/v11i1/8157

Bakar, N. A., Shuaibu, A., \& Bakar, R. A. (2017). Correlation of Self-Regulated Learning and Academic Achievement among Universiti Sultan Zainal Abidin (UniSZA) Undergraduate Students. International Journal of Academic Research in Business and Social Sciences, 7(4), 254-267. https://doi.org/10.6007/ijarbss/v7-i4/2804

Chuan, M., Pei, T., Shen, D., Yu, W., Lynne, C., Hsu, C., \& Wen, C. (2019). Exploring the effects of web - mediated activity - based learning and meaningful learning on improving students' learning effects, learning engagement, and academic motivation. Universal Access in the Information Society, 0123456789. https://doi.org/10.1007/s10209-01900690-x

Corrin, L., Kennedy, G., de Barba, P. G., Lockyer, L., Gasevic, D., Williams, D., Dawson, S., Mulder, R., Copeland, S., \& Bakharia, A. (2016). Completing the Loop: Returning Meaningful Learning Analytic Data to Teachers.

Dey, D., Kim, A., Lahiri, A., White, J. M., Rojas, C., Briceño, A., Ugale, K. S., Mune, P. A., Deshmukh, P. H. R., Choi, P., Bae, S. H., Jun, J., Sahni, S. P., Jain, G., Gupta, I., Rang-Ding, W., Yi-Qun, X., Godinho de Matos, M., Ferreira, P., ... Telang, R. (2018). A Method of Protecting Relational Databases Copyright with Cloud Watermark. Journal of Business Ethics, 6(1), 15-27. https://doi.org/10.1007/978-3-319-63856-0

Etemadpour, R., Zhu, Y., Zhao, Q., Hu, Y., Chen, B., Sharier, M. A., Zheng, S., \& Jose, J. G. (2020). Role of absence in academic success: an analysis using visualisation tools. Smart Learning Environments, 7(1). https://doi.org/10.1186/s40561-019-0112-3

Fan, K. K., Xiao, P. W., \& Su, C. H. (2015). The Effects of Learning Styles and Meaningful Learning on the Learning Achievement of Gamification Health Education Curriculum. EURASIA Journal of Mathematics, Science \& Technology Education, 11, 1211-1229. https://doi.org/10.12973/eurasia.2015.1413a

Fan, Y., Matcha, W., Uzir, N. A., Wang, Q., \& Gašević, D. (2021). Learning Analytics to Reveal Links Between Learning Design and Self-Regulated Learning. International Journal of Artificial Intelligence in Education. https://doi.org/10.1007/s40593-021-00249-z

Fisk, P. (2017). Education 4.0 ... the future of learning will be dramatically different, in school and throughout life. Http://Www.Thege-niusworks.Com/2017/01/Future-EducationYoung-Ev-eryone-Taught-Together. 
Fox, E. M. (2020). Students Mobile Technology : A Tool to Increase Global Competency Among Higher Education Students. International Review of Research in Open and Distributed Learning.

Garfield, J., \& Ben-zvi, D. (2009). Helping Students Develop Statistical Reasoning: Implementing a Statistical Reasoning Learning Environment. Teaching Statistics: An International Journal for Teachers, 31(3), 72-77.

Gielen, S., Peeters, E., Dochy, F., Onghena, P., \& Struyven, K. (2010). Improving the effectiveness of peer feedback for learning. Learning and Instruction, 20(4), 304-315. https://doi.org/10.1016/j.learninstruc.2009.08.007

Gikas, J., \& Grant, M. M. (2013). Mobile computing devices in higher education : Student perspectives on learning with cellphones, smartphones \& social media. The Internet and Higher Education, 19, 18-26. https://doi.org/10.1016/j.iheduc.2013.06.002

Guimarães, C., César, M., Machado, O., \& Fernandes, S. F. (2018). Comic Books : A Learning Tool for Meaningful Acquisition of Written Sign Language. Journal of Education and Learning, 7(3), 134-147. https://doi.org/10.5539/jel.v7n3p134

Hairulliza, M. J., Iksan, Z. H., \& Ashaari, N. S. (2018). Implementation of Cognitive Visual Data Analytics Learning Support: Applying Meaningful Reception Learning Theory. Compusoft, 7(11), 2879-2883. https://getit.library.utoronto.ca/index.php/oneclick?ctx_ver=Z39.882004\&ctx_enc=info\%3Aofi\%2Fenc\%3AUTF-

8\&rfr_id=info\%3Asid\%2Fsummon.serialssolutions.com\&rft_val_fmt=info\%3Aofi\%2Ffmt \%3Akev\%3Amtx\%3Ajournal\&rft.genre=article\&rft.atitle=IMPLEMENTATION+OF+COG

Hairulliza, M. J., Iksan, Z. H., \& Ashaari, N. S. (2019). Cognitive Visual Support Design for Efficient Data Analytics Learning Based on Meaningful Reception Learning Theory. 4, 194-198.

Hairulliza, M. J., Roslinda, R., \& Capraro, M. M. (2018). Meaningful Statistics Learning Using Gamification. International Conference on Advances in Computer Science, Engineering and Technology ICACSET18.

Haron, H. (2018). Education in the Era of IR 4 . 0. 2018 International Conference on Information Management and Technology (ICIMTech.

Hussin, A. A. (2018). Education 4 . 0 Made Simple : Ideas For Teaching. International Journal of Education \& Literacy Studies, c, 92-98.

Ismail, E. A., \& Groccia, J. E. (2018). Students Engaged in Learning. NEW DIRECTIONS FOR TEACHING AND LEARNING, 154, 45-54. https://doi.org/10.1002/tl.20290

Janati, S. E. L., Maach, A., \& Ghanami, D. El. (2019). Learning Analytics Framework for Adaptive E-learning System to Monitor the L earner's Activities. 10(8), 275-284.

Karatas, K., \& Arpaci, I. (2021). The role of self-directed learning, metacognition, and 21st century skills predicting the readiness for online learning. Contemporary Educational Technology, 13(3). https://doi.org/10.30935/cedtech/10786

Liu, M.-C., \& Huang, Y.-M. (2017). The use of data science for education: The case of socialemotional learning. Smart Learning Environments, 4(1), 1-13. https://doi.org/10.1186/s40561-016-0040-4

Maisurah, K., \& Bahador, K. (2012). Information Technology Competencies for Malaysian Accountants - An Academic's Perspective The Changing Roles of Accountants. 1-12.

Majid, N. A. A., \& Majid, N. A. (2018). Augmented reality to promote guided discovery learning for STEM learning. International Journal on Advanced Science, Engineering and Information Technology, 8(4-2), 1494-1500.

Rosly, M. R., \& Khalid, F. (2017). Gamifikasi : Konsep dan Implikasi dalam Pendidikan. 
Pembelajaran Abad Ke-21 : Trend Integrasi Teknologi, 144-154.

Munguia, P., Brennan, A., Taylor, S., \& Lee, D. (2020). A learning analytics journey: Bridging the gap between technology services and the academic need. Internet and Higher Education, 46(May), 100744. https://doi.org/10.1016/j.iheduc.2020.100744

Nguyen, A., Gardner, L., \& Sheridan, D. (2020). Data analytics in higher education: An integrated view. Journal of Information Systems Education, 31(1), 61-71.

Nguyen, A., Wandabwa, H., Rasco, A., \& Le, L. A. (2021). A Framework for Designing Learning Analytics Information Systems. Proceedings of the 54th Hawaii International Conference on System Sciences, 4-13. https://doi.org/10.24251/hicss.2021.002

Noroozi, O., Alikhani, I., Järvelä, S., Kirschner, P. A., Juuso, I., \& Seppänen, T. (2019). Multimodal data to design visual learning analytics for understanding regulation of learning. Computers in Human Behavior, 100, 298-304. https://doi.org/10.1016/j.chb.2018.12.019

Pelikan, E. R., Lüftenegger, M., Holzer, J., Korlat, S., Spiel, C., \& Schober, B. (2021). Learning during COVID-19: the role of self-regulated learning, motivation, and procrastination for perceived competence. Zeitschrift Fur Erziehungswissenschaft, 24(2), 393-418. https://doi.org/10.1007/s11618-021-01002-x

Priniski, S. J., Hecht, C. A., Harackiewicz, J. M., Priniski, S. J., Hecht, C. A., \& Making, J. M. H. (2018). Making Learning Personally Meaningful: A New Framework for Relevance Research Making Learning Personally Meaningful: A New Framework for Relevance Research. The Journal of Experimental Education, 86(1), 11-29. https://doi.org/10.1080/00220973.2017.1380589

Ramli, I. S. M., Maat, S. M., \& Khalid, F. (2019). Learning Analytics in Mathematics: A Systematic Review. International Journal of Academic Research in Progressive Education and Development, 8(4), 436-449. https://doi.org/10.6007/ijarped/v8-i4/6563

Saqr, M. (2018). Using Learning Analytics to Understand and Support Collaborative Learning. Stockholm University PhD Thesis.

Selamat, A. (2017). Educational Technology as a Key to Unlocking the Fourth Industrial Revolution -Malaysian Higher Learning Perspectives. International Conference on University 4.0, Nguyen Tat Thanh University, Ho Chin Minh, Vietnam.

Serban, C., \& loan, L. (2020). QLearn: Towards a framework for smart learning environments. Procedia Computer Science, 176, 2812-2821.

https://doi.org/10.1016/j.procs.2020.09.273

Song, L., \& Hill, J. R. (2007). A conceptual model for understanding self-directed learning in online environments. Journal of Interactive Online Learning, 6(1), 27-42.

Thannimalai, R., \& Raman, A. (2018). Principals technology leadership and teachers technology integration in the 21st century classroom. International Journal of Civil Engineering and Technology, 9(2), 177-187.

Vaithilingam, C. A., Gamboa, R. A., \& Lim, S. C. (2019). EMPOWERED PEDAGOGY : CATCHING UP WITH THE FUTURE. Malaysian Journal of Learning and Instruction, 16(1), 1-22.

Vallori, A. B. (2014). Meaningful Learning in Practice. Journal of Education and Human Development, 3(4), 199-209. https://doi.org/10.15640/jehd.v3n4a18

Viberg, O., Khalil, M., \& Baars, M. (2020). Self-regulated learning and learning analytics in online learning environments: A review of empirical research. ACM International Conference Proceeding Series, March, 524-533.

https://doi.org/10.1145/3375462.3375483

Wieser, D. (2019). Integrating technology into the learning process of higher education : A 
creative inquiry. Industry and Higher Education.

https://doi.org/10.1177/0950422219895773

Xing, B., \& Marwala, T. (2017). Implications of the Fourth Industrial Age on Higher Education.

Yahaya, A., Maakip, I., Voo, P., Yusuf, M. Y. M., \& Ramli, N. K. B. A. (2020). Effects of Selfregulated Learning, Parental Involvement and Homework on Academic Achievement of School Students. International Journal of Academic Research in Progressive Education and Development, 9(2), 380-397. https://doi.org/10.6007/ijarped/v9-i2/7419 